\title{
EDGAR WIND. A SHORT BIOGRAPHY
}

\author{
Ben Thomas \\ University of Kent
}

Edgar Marcel Wind (1900-1971), philosopher and art historian, was born at 5 Passauerstrasse, Charlottenburg, Berlin on 14 May 1900, one of two children of Maurice Delmar Wind (d. 1914) and his Romanian wife Laura Szilard (d. 1947). Wind's father was a wealthy Argentinean merchant of Russian Jewish extraction who exported optical instruments to South America. Wind grew up in a cosmopolitan and polyglot environment, attending the Kaiser-Friedrich-Schule in Charlottenburg (1906-1918), and also benefiting from his father's excellent library. In 1918 he commenced studies at the University of Berlin in classics, philosophy and art history, supervised by Adolph Goldschmidt. The following year he attended the lectures of Edmund Husserl and Martin Heidegger in Freiburg, and those of Max Dvorak, Julius von Schlosser and Josef Strzygowski in Vienna. Unimpressed, however, with the „reigning sovereigns”, Wind turned to Hamburg University where he became Erwin Panofsky's first pupil, and engaged with the Neo-Kantianism of Ernst Cassirer.

In his doctoral thesis of 1922 Ästhetischer und kunstwissenscaftlicherGegenstand, examined by Erwin Panofsky and Ernst Cassirer, Wind rejected romantic and formalist approaches to the appreciation of art which emphasized aesthetic response over historical analysis (Wind 1924, Wind 2011, Wind 1925: 438-486). Wind's concern in his dissertation was to explore the methodological paradox that the art historian's attempts at rational scientific analysis were grounded on aesthetic judgments that were intrinsically irrational: an insoluble contradiction. He was concerned to analyze Kantian concepts of aesthetic judgment, and how the object of aesthetic judgement is transformed into an object of historical analysis through emphasizing the role of style 1 . In a related article published in 1925, Wind demonstrated how, distinguishing between aesthetics and art theory, the art critic and art

${ }^{1}$ For Wind's doctoral dissertation and his early philosophical work on art historical methodlogy see: Ferretti 1991: 346-357. 
historian were both engaged in critical analysis and judged the artist's performance according to a hypothetical rather than categorical imperative, the first as solutions to artistic problems, the second as historical events (Wind 1925c: 350-359). Wind would later summarize his approach as one which demonstrated that the intellect aided, rather than thwarted, the imagination in producing great works of art: „I have tried to develop a method of interpreting pictures which shows how ideas are translated into images, and images sustained by ideas" ${ }^{2}$. Wind would also later recall how he accidentally met Panofsky on the way to the examination of his doctorate on 29 July $1922-$ an intriguing anecdote that suggests the mutual respect and influence that existed between these two scholars at this time. While they were walking in the street Wind and Panofsky had ,a long and funny conversation”, but then as they approached the university Panofsky felt „our intimacy might be regarded as unbecoming in official quarters' and suggested that Wind go in first while he walked around the building. „On his arrival he greeted me as if he had never seen me in his life" (Heckscher 1969: 12-13).

At the height of the German depression in 1924, Wind left for the United States. After briefly teaching French and Mathematics in New York High Schools, he was appointed Lecturer in Philosophy at the University of North Carolina at Chapel Hill, where he encountered and was profoundly influenced by the pragmatism of Charles Sanders Peirce. Wind always acknowledged Peirce, along with Aby Warburg, as one of the two fundamental influences on his thought. A sense of Wind's philosophical range, acute insight, and shifting position can be glimpsed in a series of reviews written at this time for the Journal of Philosophy, notably the 1925 summary report on contemporary trends in German philosophy which ranges from the Marburg School Neo-Kantianism of Hermann Cohen to the phenomenological approach of Edmund Husserl (Wind 1925a: 477-493). The bulk of this article involves a respectful account of Ernst Cassirer's development of Neo-Kantianism in a more cultural direction and a critique of Heinrich Rickert's philosophy. It was during this first American period of Wind's life that he met his first wife Ruth Hatch, to whom he was married from 1926 until 1934.

On his return to Hamburg in 1927, Wind met Aby Warburg, becoming his personal research assistant at the Bibliothek Warburg, the extraordinary private research institute and library created by Aby Warburg and dedicated to the cultural historical study of the afterlife of classical cultures. Warburg's example had a decisive impact on Wind's development as a scholar,

${ }^{2}$ Wind Archive, Special Collections, Bodleian Library, Oxford (hereafter Wind Archive), I, 9, VI: application for a Guggenheim grant, 1950. 
encouraging him - previously a philosopher and theoretician concerned with the methodological problems of art history - to concentrate on significant historical detail and its creative transformation into cultural imagery. Warburg, in turn, was impressed by Wind, remarking „Ich vergesse immer daß Sie eingeschulter Kunsthistoriker sind. Sie haben es ja so nett mit dem Denken"'. In 1930, after Warburg's death, Wind delivered an important lecture on „Warburg's Concept of Kulturwissenschaft” which gave a lucid explanation of the theory of the polarity of the symbol, and distanced Warburg's method from the formalist art historical approaches of Alois Riegl and Heinrich Wölfflin (Wind 1931: 163-179)4. The intellectual closeness of Wind and Warburg during this period was acknowledged by other members of the Warburg circle like Fritz Saxl and Gertrud Bing, and from the evidence of a letter written to Jean Seznec in 1954 it seems that Wind felt continually haunted by the burden of responsibility, towards his library and ideas, that Warburg's personal trust in him implied ${ }^{5}$.

Wind became a Privatdozent at Hamburg University in 1930 following the completion of his Habilitationsschrift Das Experiment und die Metaphysik (Wind 1934) ${ }^{6}$. This remarkable philosophical work tackled the problem of circular argument in both the sciences and humanities, advanced a theory of the experiment based on ,internal delimitation” as an empirical method for testing hypotheses, and proposed ways in which Kant's four cosmological antinomies could be resolved through a critique of their underlying Newtonian assumptions regarding space and time in the light of scientific advances such as the theory of relativity and quantum mechanics. Fundamental here is Wind's notion of „embodiment” - the conceptual link between a pragmatist revision of Kant and a Warburgian understanding of the symbol. Unfortunately, Wind's philosophical masterpiece fell victim to the political changes occurring in Germany (it was only published in 1934), and it had very few readers. One of these was Cassirer, who saw it as a lapse into empiricism. Wind later recalled: „I am sorry to say it made that amiable man extremely angry" (Wind 1958: 297).

\footnotetext{
${ }^{3}$ Buschendorf 1993: 85 („I always forget that you are a trained art historian. You know how to think so nicely").

${ }^{4}$ Reprinted in translation in the posthumous collection of essays: Wind 2009: 20-35. See also: Wind 2009: 83-111.

${ }^{5}$ Letter to J. Seznec (Wind Archive, I, 5, IV): the dying Warburg had confided in Wind that "«C'est simple. J'aurais toujours peur de mourir et vous savez pourquoi. Mais Depuis que vous êtes dans cette bibliothèque, je n'ai plus peur; je sais que tout ira bien quand je serai parti». Il est mort un mois plus tard".

${ }^{6}$ Second German edition: Wind 2001a; English translation: Wind 2001b.

7 See also: Engel 2012: 369-392.
} 
It was at this time that Wind also produced his first major art historical work (although one profoundly shaped by philosophical issues): a study associating the different portrait styles of the eighteenth-century English painters Joshua Reynolds and Thomas Gainsborough with James Beattie, Edmund Burke and Samuel Johnson on the one hand, and with David Hume on the other (Wind 1932: 156-229) ${ }^{8}$. To treat English painting of the Enlightenment period as the object of serious critical analysis, as Wind did here, was very innovative at a time when British art was certainly not thought to be capable of sustaining the type of critical analysis usually reserved for Renaissance masterpieces, and he therefore deserves to be remembered as one of the pioneers of the study of British art.

Wind was dismissed from his post at Hamburg shortly after Hitler's rise to power in 1933. At a conference on Science and Freedom held in Hamburg in 1953, Wind paid tribute to the actions at this time of his friend, the classicist Bruno Snell, who tried to organize a resistance to the political alignment of German universities to the Nazi party under the "Gleichschaltung". Snell's initiative failed because older academics at Hamburg saw it as ,an empty gesture” and refused to support his objections to the new authorities imposed on the university. Wind's bitter disillusionment with the tradition of German Idealist philosophy stems from this failure, as can be seen from two highly critical paragraphs deleted from the published version of the preface to Experiment and Metaphysics (Wind 2001b: $2-3)^{9}$. Wind wrote in these deleted passages:

Is it not here, in philosophy itself, that the guilt of those most prominent representatives of that "Idealism" which is today condemned as "liberal" lies? Possessing and enjoying a philosophy which they thought to be adequately anchored in a glorious tradition, at the critical moment they proved neither willing nor able to fulfil their logical obligations. Challenged to battle, they had the choice of weapons, but they preferred to behold from on high the development in which they ought to have intervened, to woo the enemy through tokens of their favour, and, despite all their wisdom, to pin their hopes on the illusion that they might be able to make their peace even with this enemy ${ }^{10}$.

\footnotetext{
${ }^{8}$ Reprinted in translation in the posthumous collection Hume and the Heroic Portrait (Wind E. 1986: 1-52). See also: Busch 1998: 33-48.

${ }^{9}$ For Wind's Hamburg speech see: Wind 1954: 280-81.

${ }^{10}$ Wind 2001b: 2, 3, note 2 - Nigel Palmer here discusses how far this criticism of „idealist” philosophers extends: ,the criticism is certainly directed at Henrich Rickert in Heidelberg... but it may also extend to others such as Bruno Bauch and the Hamburg professors who declined to stand by Bruno Snell in his protest against the National Socialist regime”.
} 
Similarly, Wind argued that the philosophical opponents of an idealistic conception of freedom that had become ,vacuous and shallow in its impotent universality" had simply withdrawn into a "gloomy Innerlichkeit" with their own refusal to intervene - and here Wind had in mind Karl Jaspers and Martin Heidegger whose work he saw as defining the „current tenor of philosophy”" Whether idealistic or „existential” in its justification, the failure to resist the „Gleichschaltung” was an „ethical error" according to Wind's concept of freedom as defined in Experiment and Metaphysics. By contrast Snell's conduct confirmed Peirce's view that theory and practice could not be divorced and that, as Wind went on to argue in his Hamburg speech in 1953, ,if you want to know a man's beliefs with regard to a given proposition, there is no better test than to observe his behaviour” (,...wenn man den Glaubeneines Menschen mit Bezug auf einen gegebenen Satz untersuchen will, es kein besseres Mittel gibt, als seine Handlungs weise zu beobachten") (Wind 1954: 280-281) ${ }^{12}$. A further comment from Wind on the relationship between philosophy and the rise of Nazism can be found in the memoirs of the dancer Agnes de Mille, with whom Wind had a love affair in London in 1934: „He understood European politics and prayed that some nation, France or Great Britain, would call Hitler's bluff... He asked me, «Have you read Mein Kampf?» Of course, I hadn't. Wind knew the philosophers and writers who had influenced Hitler and he was alarmed" (de Mille 1973: 314).

Nazi anti-semitism endangered the Bibliothek Warburg, and Wind played a decisive role in negotiating the transfer of Warburg's library to London. Fritz Saxl had succeeded in finding a second home for the library in Leiden, but not the funding to effect the transfer. Wind, however, was introduced in London by his distant relative the Hon. Mrs Ernest Franklin to a network of supportive figures including Sir Philip Hartog, Dr. C. S. Gibson, W. G. Constable (Director of the Courtauld Institute of Art) and Sir Denison Ross (Director of the School of Oriental Studies). With the financial backing of Samuel Courtauld it was possible to move the library to Thames House in London just before decisions regarding emigration were centralized in Berlin. Shortly afterwards Wind's introduction to the Kulturwissenschaftliche Bibliographiezum Nachleben der Antike,

\footnotetext{
${ }^{11}$ Heidegger, of course, actively embraced National Socialism in his tenure of the rectorship of the University of Freiburg. See, for example: Safranski 1998: 225-263, Ott 1993: 133-260, Faye 2011.

${ }^{12}$ For the source in Peirce see, for example, Peirce 1955: 30: ,Thus, we come down to what is tangible and conceivably practical, as the root of every real distinction of thought, no matter how subtle it may be; and there is no distinction of meaning so fine as to consist in anything but a possible difference of practice".
} 
published by the Bibliothek Warburg, was attacked as a critique of Geistgeschichte in Goebbels' newspaper the Völkischer Beobachter (Lloyd Jones 1983: XIX) ${ }^{13}$. From 1934 Wind was Deputy Director of the Warburg Institute, and in 1937 became founding editor with Rudolf Wittkower of the Journal of the Warburg Institute in which he published his first iconographical studies of Renaissance works of art. In lectures given in London at this time he advanced interpretations of the works of Michelangelo and Raphael with which he was absorbed for the rest of his life.

At the outbreak of the Second World War in 1939 Wind found himself on sabbatical leave in America at St. John's College Annapolis, at the invitation of Scott Buchanan and Stringfellow Barr, two scholars whose reforming approach to education he sympathised with and had participated in at The Cooper Union in New York during the 1920s. After the fall of France, Wind's Warburg colleagues sent him a telegram requesting that he stay in the USA, in the common interest" ${ }^{14}$. During 1940 Wind succeeded in securing an offer from the Library of Congress, the National Gallery and the Dumbarton Oaks Research Library to jointly give the Warburg library and staff a home. Through these talks Wind became acquainted with the poet Archibald MacLeish who had been appointed Librarian of Congress in 1939 by President Roosevelt. MacLeish's controversial 1940 essay The Irresponsibles, in which he urged intellectuals to wake up to their responsibility to fight against fascism in the cultural arena, resonated with Wind as an exiled Jewish academic (MacLeish 1940). Although it proved too dangerous at this time to transfer the Warburg Institute's collection of rare books to America, Wind's work in Washington strengthened the hand of the Institute's Director Fritz Saxl in negotiating the Warburg Institute's incorporation into the University of London during 1943-1944.

Wind then embarked on an extraordinary peripatetic tour across America giving successful lectures that were widely regarded ,as expositions of the method to which the Warburg Institute in London was committed"15. Leading institutions at which Wind lectured included Harvard, Yale, Columbia, Princeton, the Metropolitan Museum of Art, the Pierpont Morgan Library, the Frick Collection, but also at universities across the Southern and Mid-Western States and along the West Coast. Particularly noteworthy was the lecture series „The Tradition of Symbols in Modern Art” given at the Museum of Modern Art in New York in 1942, where Wind applied

\footnotetext{
13 See also: Buschendorf 1993: 85-128.

14 Wind Archive, I, 5, I: telegram, 21 May 1940.

15 Wind Archive, I, 5, I: Edgar Wind, report to Fritz Saxl on his American activities, 1945.
} 
his historical method to twentieth-century art, including the works of his friend the Russian painter Pavel Tchelitchew whose famous Hide and Seek (1940-1942) he saw as a „magic picture” (Tyler 1967: 118-119). In 1940 Wind met Margaret Kellner, the daughter of the physicist G. A. Hermann Kellner. She became his research assistant, and they married in 1942. As his literary executor after 1971, she was the driving force behind the posthumous publication of his papers ${ }^{16}$.

Wind held the temporary post of Lecturer at the Institute of Fine Arts, New York University from 1940 during this period of frenetic activity. In 1942, tired of the relentless travelling and uncertainty that this state of affairs involved, Wind accepted a post at the University of Chicago - a move that his colleagues at the Warburg Institute interpreted somewhat despairingly as a desertion. For example, Gertrud Bing, the Deputy Director of the Warburg Institute, wrote to Wind: „I cannot imagine the future of the Institute to be quite as satisfactory as we had all hoped without your presence" 17 . Wind made it clear, however, that it was his intention to resign his post and return to London as soon as the war ended. At Chicago, Wind assisted the Chancellor of the University, Robert Hutchins, in developing experimental inter-disciplinary approaches to teaching as part of the newly-founded Committee on Social Thought (which introduced the so-called Great Books programme). Wind described the ,atmosphere of martial violence" created at Chicago in reaction to Hutchins' ideas, with which he was closely associated, with events coming to a head when opponents of the reforms attempted to use a committee on policy to prevent Wind from speaking in public on humanities subjects ${ }^{18}$. It was with some relief that Wind left Chicago to take up the temporary position of Neilson Research Professor at Smith College, Northampton MA, in 1944.

At the end of the war, Wind chose to remain at Smith as Professor of Philosophy and Art, and he became an American citizen in 1948. This surprising decision, when his possessions were already in storage ready for shipping to London, resulted from a difficult visit by Saxl to Smith College in 1945 when it became clear that his views on the future direction of the Warburg Institute had diverged markedly from Wind's. The two scholars disagreed over academic projects, staffing policy and the hierarchical

\footnotetext{
${ }^{16}$ Notably with the posthumous collections The Eloquence of Symbols. Studies in Humanist Art (Wind 1983) and Hume and the Heroic Portrait. Studies in Eighteenth-Century Imagery (Wind 1986), both edited by Jaynie Anderson, and The Religious Symbolism of Michelangelo (Wind 2001c) edited by Elizabeth Sears.

${ }^{17}$ Gertrud Bing to Edgar Wind, 27 April 1942.Wind Archive, I, 5, II.

${ }^{18}$ Edgar Wind, report to Fritz Saxl on his American activities, 1945. Wind Archive, I, 5, I.
} 
structure that the Warburg Institute had adopted after its incorporation into the University of London. Ultimately, however, Wind was motivated by an ethical concern to stay true to Warburg's ideas and methods. Correspondence with Kenneth Clark at the time of Saxl's death in 1948, reveals shared concerns that the Warburg Institute would inevitably become ,an ordinary learned body”, while „Warburg himself used to feel that certain phases of his work might not be at their best if they became codified in an orthodox fashion"19. Wind felt certain that his decision to stay true to the idea of Kulturwissenschaft by resigning from the Institute would have had Warburg's approval, relying on his own sense of their particular closeness in approach and understanding.

At Smith Wind continued to develop his research into Renaissance art, publishing studies of the iconography of the Sistine Chapel ceiling (1947) and Giovanni Bellini's Feast of the Gods (1948) (Wind 1947: $211-$ 246, Wind 1948a). He also continued to practice an innovative approach to teaching, for example developing the Sophomore course Humanities 292a „The Traditional Conflict between Reason and Myth” where ,the work of every week is planned on the basis of the confusions which the lecture of the week before aroused, so that the whole, as I see it, is not an orientation course but a disorientation course, whose purpose is to break up prejudices. And when new ideas are bred, these in turn create new prejudices which I hastily try to break up again. It is a slightly explosive process" ${ }^{20}$. Wind's teaching at Smith also focused on „The Platonic Tradition”, exploring in depth Neoplatonism from Plotinus and Proclus to such Renaissance figures as MarsilioFicino and Pico della Mirandola: a field where Wind's superb knowledge has been praised by leading historians of philosophy like Pierre Hadot $^{21}$. An affectionate and insightful remembrance of Wind as a teacher at Smith is provided by Clare Goldfarb: „The first words I heard from the mouth of Edgar Wind, Professor of Philosophy and Art at Smith College, were «Does God have a beard?»... Leaning forward on his elbows, fingers laced together, he would start with a question that seemed to bear no resemblance to anything we had read for him. Somehow by the end of the class we were talking about those readings - and wrestling with one of his questions. This was a class with no small talk, no attempts at making us «comfortable»... None of that stuff mattered because we all knew - even

\footnotetext{
19 Wind Archive, I, 5, II: Kenneth Clark to Edgar Wind, 16 June 1948.

${ }^{20}$ Wind Archive, Box 12, I, 9, II: Smith Alumnae Quarterly, May 1953, p. 136.

21 See: Krois 1998: 181-205, particularly: 202-205, Klibansky 1992: 28-32, Hadot 1992, German translation: Hadot 1998: 251-257.
} 
as we were sweating it out - that the course was one of the important experiences of our college lives" (Goldfarb 1999: 125-134).

In 1952 Wind advanced a sophisticated interpretation of Leonardo da Vinci as a Heraclitan magus in a series of radio broadcasts for the BBC's Third Programme, transcripts of which were published in The Listener without his knowledge or approval (Wind 1952a: 705-706, Wind 1952b: 748, Wind 1952c: 788). Although these transcripts are littered with mistakes, they provide precious evidence of Wind's lecturing style, as he always lectured without a text, and also of the argument of the book on Leonardo he intended to write but never started. According to Wind, Leonardo's „exact lyricism” arose from an artistic sensibility founded on mathematical understanding. Plato's Timaeus, known to Leonardo through friends at the Milanese court of Ludovico Sforza like the mathematician Luca Pacioli, described a cosmos in flux but based on geometrical regularity: the so-called „Platonic" regular solids representing the elements of fire, water, earth and air, which constantly recombine to form the semi-regular solids that temporarily hold together violently opposing natural forces. Man as a microcosm was also subject to emotional and physical change evident in each individual's physiognomy, and which could be broadly categorized according to the theory of the four humours (choleric, sanguine, phlegmatic and melancholic). Leonardo brought to bear these profound insights in his Last Supper where the disciples react to Christ's announcement of his betrayal on one side of the table with dismay, while on the other side Christ's institution of the Eucharist is accepted ecstatically. The great mural represents, therefore, a muti-layered statement of a profound mystery, intended to sustain richly nuanced readings and not simply represent a moment in time, and thereby to achieve - a typical Renaissance theme for Wind - the reconciliation of opposites to produce harmony.

Wind also engaged in debates about contemporary art and ideas: a visit by Jean-Paul Sartre to Smith College in 1946 provoked an impassioned statement against existentialism as a revival of Heidegger's „thoroughly evil” philosophy ${ }^{22}$; while in 1947 he clashed with E. M. Forster over the moral purpose of art in a debate on the subject of Music and Criticism at Harvard University (Wind 1948b: 55-72). Wind's forcefully expressed views on art, its potentially disruptive power (following Plato), and its marginality in contemporary society in relation to science (adapting Hegel), brought him recognition as a leading critic - but were also sometimes misunderstood as advocating censorship. In fact he was calling for a more engaged

${ }^{22}$ Wind 1946a: 1-4, reprinted as Wind 1946b: 54-7. See now: Bredekamp 1998: 207-26. 
patronage of the arts guided by morally informed criticism. Wind pithily summarized his complex views on the relationship between art and society in his Art and Anarchy lectures, using the image of the temple: „When we treat art as sacrosanct we clearly refer to the temple and to nothing else: there the artist is necessarily alone with his genius. But in the forecourt he should not be left alone. And yet we leave him alone there as well, because we mistakenly extend to the porch the same veneration as belongs to the sanctuary" (Wind 1985: 78).

In 1952 Wind was invited by the composer Nicolas Nabakov to participate in the Masterpieces of the Twentieth Century arts festival that he was organizing in Paris. This initiated a brief period in which Wind participated in the activities of the Congress for Cultural Freedom, a prominent anti-communist organization promoting the cultural advantages of democratic freedom and which, controversially, was covertly funded by the CIA. In addition to participating in the Paris festival, Wind spoke at the Hamburg conference on Science and Freedom and participated in the Alpbach seminar organized by the CCF in 1953. As a friend of figures like Isaiah Berlin and Sidney Hook who had close links with diplomatic and political circles, Wind's involvement in the CCF was certainly not naïve or opportunistic but consistent with a liberalism rooted in the Enlightenment (Wind was registered as a Democrat voter in the USA). Through this organization Wind associated with some of the leading intellectuals, critics and artists of the day - debating in Paris, for example, with Herbert Read and Lionello Venturi, and meeting the writers Albert Camus and W.H. Auden. It was in this Cold War context that he developed many of the themes that would later inform the writing of Art and Anarchy.

Wind's commitment to intellectual integrity was again demonstrated in 1953 when he organized and contributed to a symposium on Art and Morals at Smith College, where the participants included Archibald MacLeish, W. H. Auden, the architect Philip Johnson, and the artist Ben Shahn: one consequence of these lively debates was the dedication to Wind of W. H. Auden's poem „The Truest Poetry Is the Most Feigning”. The Art and Morals symposium occurred at a time of political tension at Smith College at the height of Senator Joseph McCarthy's influence (Buschendorf 1998: 117-134) ${ }^{23}$. Following the testimony of a colleague, the literary critic Robert Gorham Davis, to the House Committee on Un-American Activities, Wind had assumed the position of a ,very effective, subtle and formidable leader of the opposition" to attempts to purge Smith of suspected com-

23 See also: Zorach 2007: 190-224. 
munists $^{24}$. At this time Wind's political position diverged from that of his friend the pragmatist philosopher Sidney Hook, who argued in Heresy, Yes - Conspiracy, No (1953) that while a liberal society should support dissenting opinions, it could not allow active conspiracies to overthrow the democracy that allowed such dissent, and that because membership of the Communist Party effectively meant participation in such a conspiracy, communist teachers and professors should be dismissed from their posts ${ }^{25}$. Arguably Wind took the more pragmatist approach in arguing that academics and teachers „should be judged by performances only" 26 .

The idea of creating a chair in the History of Art at Oxford University had been promoted for some time by scholars who had known Wind since the 1930s, including Richard Livingstone, Ernest Jacob, Maurice Bowra and Isaiah Berlin. In 1954 Wind was invited to give the Chichele lectures at All Souls College and chose as his subject „Art and Scholarship under Julius II". When the chair was created in 1955, Wind was appointed to it, becoming a Professorial Fellow at Trinity College. Wind faced the difficult task of establishing a new discipline in an ancient institution. In order to promote a cultural historical approach to the study of art, as distinct from the curatorial interests of the Ashmolean Museum, Wind argued for the creation of a new department with its own research library. He amassed a noteworthy collection of books, including many early editions, which together with his own personal library, subsequently became the Wind Reading Room in the Sackler Library.

It is, above all, as a brilliant and charismatic lecturer that Wind is remembered at Oxford. He spoke without notes, showing only one black and white slide at a time. The popularity of his lectures made it necessary for the Playhouse Theatre, the largest auditorium in Oxford at the time, to be used as a venue; the long queues for his series of lectures on Modern Art were even reported in the Oxford Times. In his 1957 Inaugural Lecture on "The Fallacy of Pure Art", Wind argued that the art historian should make observations which are ,aesthetically relevant without being aesthetic observations" ${ }^{27}$. The list of subjects to which Wind applied this maxim in his regular lectures demonstrates the wide scope of his learning. In particular, he gave classes with other scholars to promote inter-disciplinary research on subjects as diverse as Kant and Hegel, Manet and Mallarmé, Renaissan-

\footnotetext{
${ }^{24}$ Isaiah Berlin to Anna Kallin, 15 October 1953 in Berlin 2011: 393-394. See also Wind's own letter to Anna Kallin of 17 July 1954: Wind Archive, III, 6, IV.

${ }^{25}$ See the discussion in Hook's memoir: Hook 1987: 498-508.

${ }^{26}$ Margaret Wind to Edgar Wind, July 1953. Wind Archive, I, 12, II.

27 Wind Archive, I, 15, II.
} 
ce medals, and Renaissance poems and their visual counterparts (with Stuart Hampshire, Austin Gill, Humphrey Sutherland and John Sparrow). The artist R. B. Kitaj, who studied at the Ruskin School of Drawing and Fine Arts from 1958 to 1961, was one of those who attended and was inspired by Wind's lectures in Oxford. Kitaj showed Wind his drawings and was in turn introduced by him to Warburg's serpent ritual lecture - the artist acknowledged the ,very great influence" that Wind had on his development at the time of his 1994 Tate Gallery retrospective ${ }^{28}$.

It was while he was Professor of the History of Art at Oxford that Wind published the two works for which he is now best known: Pagan Mysteries in the Renaissance (1958, revised edition 1967) and Art and Anarchy (originally given as the 1960 BBC Reith lectures). The former is a brilliant scholarly work in which Wind elucidated the obscure Neo-Platonic mysteries which inspired some of the greatest works of the Renaissance. Wind anticipated the criticism that he attributed to artists like Botticelli a depth of learning which they never possessed. He argued that the historian has to be more erudite than the artists he studies because "we no longer enjoy the advantages of Renaissance conversation" (Wind 1967: 15). In Art and Anarchy, Wind explored the causes and effects of the marginalization, mechanization, and mass distribution of art in contemporary society. $\mathrm{He}$ examined the polarities of ,art for art's sake” and art engagé, deplored the dissociation of the artist from the educated and informed patron, the everwidening gap among modern artists between imagination and learning, and the transformation of the work of art into an object of ,interest”. All these trends, he argued, have served to tame the anarchic energies of art and dilute the imaginative forces of both artists and their audience.

Wind retired from the Chair at Oxford in 1967. He had been suffering from leukaemia since 1965 but, despite ill health, he continued to work on his book on Michelangelo's theological sources. A shorter work on Giorgione's Tempesta was published in 1969, offering an ingeniously simple explanation for the famously enigmatic work (Wind 1969). Wind's presence was imposing, even magisterial: he dressed formally and spoke a very elegant English, tinged with a German accent. The high standards of scholarship which he maintained, and expected from others, could seem daunting; but those who came to him for advice, whether students, colleagues or friends, were treated with kindness, patience and understanding. Edgar Wind died in London on 12 September 1971.

${ }^{28}$ R.B. Kitaj to Margaret Wind, November 1993 Wind Archive, III, 6, VII. See: Chaney 2013.

\section{/ $128 \quad$ STANRZECZY 1[8]/2015}


In a critical review of the posthumously published collection of essays The Eloquence of Symbols, Creighton Gilbert remarked that Wind was remembered by fellow art historians for a combination of ,abstruse erudition" and „scintillating talk" but that his career amounted to ,a classic, even a heroic, tragedy". He had failed to deliver the major study of Michelangelo that had been his life's work, and his few and short books were in effect, ,sets of lectures" (Gilbert 1984: 36-42). This analysis is partially true: Wind was overshadowed by Erwin Panofsky in the USA and by Ernst Gombrich in the UK as exponents of the iconographical method he had done so much to introduce to both countries, and the fame of those two great scholars eclipsed Wind's arguably closer relationship and intellectual affinity with Aby Warburg. This fact goes some way to explaining the ferocity of Wind's unfairly critical review of Gombrich's biography of Warburg in 197129.

Gilbert, however, underestimated Wind's enduring influence, even while admitting that Art and Anarchy had been translated into six languages (now nine, while Pagan Mysteries in the Renaissance has been translated into six). Whenever a major Renaissance painting like Botticelli's Primavera is reassessed, then the interpretation originally advanced by Wind often holds up as the most subtle, formative and enduring ${ }^{30}$. The leading Hogarth scholar Ronald Paulson has admitted to a sense of ,unease” on reading the collection of essays Hume and the Heroic Portrait, because „I had forgotten some of my own indebtedness, long since absorbed beyond footnoting, and sometimes, I fear, attributed to a later scholar when it should have been to Wind'. Wind's influence, although fundamental, had been forgotten because „Wind, unlike Warburg, Panofsky, and Gombrich, has always been, for me, a series of discrete essays and books and not a unified theory". Also, while praising original insights that shaped the terrain of art historical research into eighteenth-century British art, Paulson was critical of Wind's tendency to force generalizations about painting and philosophy to merge - mapping too neatly, for example, Hume's scepticism with Gainsborough's painterly style, when Hogarth's theoretical views are better documented as being closer to Gainsborough (Paulson 1987: 472-475). Similarly, Leo Steinberg credited Wind for his perceptively „premature" recognition of the ambiguities in Leonardo da Vinci's Last Supper that allowed a Eucharistic reading to complicate the then traditional interpretation (following Goethe) of the work as a secular psycho-

${ }^{29}$ Review of E. H. Gombrich, Aby Warburg. An Intellectual Biography (Gombrich 1971: 735-736). See also: On a recent Biography of Warburg (Wind 1983: 106-113).

${ }^{30}$ See, for example, Dempsey 1997. 
drama of betrayal, but he also criticised Wind for the „extravagant” claim that ,the four groups of Apostles symbolize the four modes of scriptural exegesis and the four Temperaments" (Steinberg 2001: 45).

Wind was fond of quoting William James on the „knights of the razor": those philosophers and scholars who misuse Occam's law of parsimony by taking interpretive short cuts, preferring not to ,wrestle with the angel” of art by actively participating in its meaning because it ,takes too long; it is uneconomical; and one is likely to get one's thigh out of joint" (Wind 1985: 87). By contrast, Wind frequently cited Peirce's maxim that our „reasoning should not form a chain which is no stronger than its weakest link, but a cable whose fibres may be ever so slender, provided they are sufficiently numerous and intimately connected" (Peirce 1934: 157). Discovering and then braiding together these elusive fibres involved extensive reading, prolonged reflection and judicious inference. This is because, as we have already seen Wind explaining in the introduction to Pagan Mysteries in the Renaissance, the historian cannot travel ,a royal road to knowledge”, as the artist did, by benefiting from ,the advantages of Renaissance conversation". The iconographical approach practiced by Wind - eschewing simplistic one-to-one connections between texts and images - was necessarily ,as Focillon observed with regret, un détour, an unavoidably roundabout approach to art" (Wind 1967: 15) ${ }^{31}$. Recovering the full significance of Wind's complex body of works - fragmented, dispersed and often unfinished as they are - could be described as a detour around a detour. Yet the patient work of research, editing and interpretation since Wind's death, initiated and guided by Margaret Wind, and more recently led by German scholars like Bernhard Buschendorf, Horst Bredekamp and John Michael Krois, has yielded remarkable results.

The publication of The Religious Symbolism of Michelangelo in 2000, for example, has allowed for a more considered evaluation of the importance of Wind's scholarship on Michelangelo than Gilbert was able to provide in 1984. Robert Gaston, for example, noted the contrast between the complex richness of Wind's reading and the minimalist interpretation of the Sistine Ceiling advanced by Gombrich in an interview with Didier Eribon: ,[Michelangelo] said he had been left free to paint whatever he liked. And what he liked was to follow tradition. There is no reason to believe that the Sistine Ceiling has more meanings than what we see" (Gombrich, Eribon 1993: 154, Gaston 2003: 797-798). While not every detail of Wind's theological interpretation holds up, drawing as it does on complex readings

${ }^{31}$ See also: Picture and Text (Wind 2001c: 192). 
of obscure sources like Sante Pagnini's Isagoge - and this fact no doubt prevented full publication of Wind's studies during his lifetime - the idea that the Sistine Ceiling functions like a magnificent concordance resonating with multiple, mystical meanings is surely more persuasive than the notion that the artist was given free rein to paint whatever he liked in the Pope's chapel. An admiring review by Paul Barolsky foresaw a „vital role” for Wind's posthumously published writings on Michelangelo in bringing about a revived and balanced intellectual history, thereby providing the means for recovering nuanced works of art from reductive readings stressing the circumstances of patronage or economic and political contexts as solely determining their meaning (Barolsky 2003: 477-478). Equally, John O'Malley has praised Wind's ,pioneering instincts, his erudition and his theological precision" in insisting on the importance of religious symbolism in interpreting the Sistine Ceiling, placing him in the vanguard of scholarship that has discovered Renaissance Rome as „perhaps the most theologically interesting and diverse centre in Europe", thus contributing to reversing the received wisdom concerning the early Sixteenth Century in the history of theology (O'Malley 2001: XLI).

Of equal significance to recent reappraisals of the mature Wind's analysis of Renaissance religious symbolism is the renewed interest in his early philosophical work. At the time of its publication in 1934, Wind complained - echoing Hume - that his remarkable philosophical masterpiece Das Experiment und die Metaphysik „fell dead-born from the Press” (LloydJones 1993: XVII). Today, however, Wind's concern to ground the practice of art history on secure philosophical foundations, and to seek out the points of contact between the humanities and the sciences, seem as timely and foresighted as his insistence on the importance of the neglected theological culture of the Renaissance. Here the key to understanding how Wind the philosopher and Wind the art historian are related is probably the significant concept of „embodiment”, although much patient work remains to be done in developing Wind's insights towards a greater interweaving of the sciences and humanities. Finally, there was always something vital at stake in the „experimentum crucis” of Wind's work as a philosopher and art historian: an urgent concern for an endangered conception of humanity. Perhaps Wind's most important lesson to us now in our threatened world is to keep alive a sense of „holy fear": ,we must remain mindful of Plato's warning that we can be prepared for the divine madness only in so far as we keep the divine fear vigilant within us" ${ }^{\prime 2}$.

32 On Plato's Pbilosopby of Art (Wind 1983: 19). 


\section{Note on Sources:}

Much of the biographical information presented here is derived from the documents in the Wind Archive in Special Collections in the Bodleian Library in Oxford. This can currently only be navigated using the manuscript catalogue created by Margaret Wind. However, a digitisation project is currently under way which should make this important archive more accessible to scholars.

I am most grateful to Robert Pawlik for his valuable help in writing this piece, his exemplary editing, and stimulating conversation. Any errors that remain are my own.

Bibliography:

/// Barolsky P. 2003. Review of „The Religious Symbolism of Michelangelo”, „Renaissance Quarterly", 56, 2, s. 477-478.

/// Berlin I. 2011. Enlightening. Letters 1946-1960, red. H. Hardy, J. Holmes, Pimlico, London.

/// Bredekamp H. 1998. Falsche Skischwünge. Winds Kritik an Heidegger und Sartre, [w:] Edgar Wind: Kunsthistoriker und Philosoph, red. H. Bredekamp, B. Buschendorf, F. Hartung, J. M. Krois, Akademie Verlag, Berlin, s. 207-226.

/// Busch W. 1998. Heroisierte Porträts? Edgar Wind und das englische Bildnis des 18. Jahrbunderts, [w:] Edgar Wind: Kunsthistoriker und Philosoph, red. H. Bredekamp, B. Buschendorf, F. Hartung, J. M. Krois, Akademie Verlag, Berlin, s. 33-48.

/// Buschendorf B. 1985. „War ein sehr tüchtiges gegenseitiges Fördern”. Edgar Wind und Aby Warburg, „Idea: Jarhbuch der Hamburger Kunsthalle”, IV, s. $165-209$.

/// Buschendorf B. 1993. Auf dem Wegnach England - Edgar Wind und die Emigration der Bibliothek. Warburg, [w:] Porträt aus Büchern, red. M. Diers, Dölling und Galitz Verlag, Hamburg, s. 85-128.

/// Buschendorf B. 1998. Zur Begrïndung der Kulturwissenschaft. Der Symbol begriff bei Friedrich Theodor Vischer, Aby Warburg und Edgar Wind, [w:] Edgar Wind: Kunsthistoriker und Philosoph, red. H. Bredekamp, B. Buschendorf, F. Hartung, J. M. Krois, Akademie Verlag, Berlin, s. 227-248. 
/// Buschendorf B. 2001. Das Prinzip der inneren Grenæsetzung und seine methodologische Bedeutung für di Kulturwissenschaften, [w:] Edgar Wind, Das Experiment und die Metaphysik, Suhrkamp, Frankfurt, s. 270-326.

/// Buschendorf Ch. 1998. Kunst als Kritk. Edgar Wind und das Symposium Art and Morals, [w:] Edgar Wind: Kunsthistoriker und Philosoph, red. H. Bredekamp, B. Buschendorf, F. Hartung, J. M. Krois, AkademieVerlag, Berlin, s. 117-134.

/// Chaney E. 2013. R. B. Kitaj (1932-2007). Warburgian Artist, „emaj”, issue 7.1, November.

/// de Mille A. 1973. Speak to Me, Dance with Me, Popular Library, New York.

/// Dempsey Ch. 1997. The Portrayal of Love. Botticelli's 'Primavera' and Humanist Culture at the Time of Lorenzo the Magnificent, Princeton University Press, Princeton.

/// Engel F. 2012. "In einem sebr geläuterten Sinne sind sie doch eigentliche in Empirist". Ernst Cassirer und Edgar Wind im Streit um di Verkörperung von Symbolen, [w:] Et in imagine ego: Facetten von Bildakt und Verkörperung, red. U. Feist, M. Rath, Walter de Gruyter, Berlin, s. 369-392.

/// Engel F. 2014. Though This Be Madness. Edgar Wind and the Warburg Tradition, [w:] Bildakt at the Warburg Institute, red. Sabine Marienberg, Jürgen Trabant, De Gruyter, Berlin, s. 87-116.

/// Faye E. 2011. Heidegger. The Introduction of Nazism into Philosophy, tłum. M.B. Smith, Yale University Press, New Haven and London.

/// Ferretti S. 1991. Edgar Wind: dalla filosofia alla storia dell'arte, „La Cultura", s. 346-357.

/// Gaston R. 2003. Review of „The Religious Symbolism of Michelangelo”, „The Burlington Magazine", 145, 1208, s. 797-798.

/// Gilbert C. 1984. Edgar Wind as Man and Thinker, „New Criterion”, 3, October, s. 36-42.

/// Goldfarb C.R. 1999. Edgar Wind and the World Famous Komodo Dragon, „The Centennial Review”, 43, 1, s. 125-134.

/// Gombrich E.H. 1971. Aby Warburg. An Intellectual Biography, „The Times Literary Supplement", 25 June, s. 735-736. 
/// Gombrich E.H., Eribon D. 1993. Looking for Answers. Conversations on Art and Science, Harry Abrams, New York.

/// Hadot P. 1992. Métaphysique et images, „Préfaces”, s. 33-37.

/// Hadot P. 1998. Metaphysik und Bilder. Ein Gespräch mit Pierre Hadot, [w:] Edgar Wind: Kunsthistoriker und Philosoph, red. H. Bredekamp, B. Buschendorf, F. Hartung, J. M. Krois, AkademieVerlag, Berlin, s. 251-257.

/// Heckscher W.S. 1969. Erwin Panofsky. A Curriculum Vitae, „Record of the Art Museum, Princeton University", 28, 1, s. 12-13.

/// Hook S. 1987. Out of Step. An Unquiet Life in the 20 th Century, Harper \& Row, New York, s. 498-508.

/// Klibansky R. 1992. Edgar Wind. Itinéraire d'un philosophe historien de l'art. Entretien avec Raymond Klibansky, „Préfaces”, s. 28-32.

/// Krois J.M. 1998. Kunst und Wissenschaft in Edgar Winds Philosophie der Verkörperung, [w:] Edgar Wind: Kunsthistoriker und Philosoph, red. H. Bredekamp, B. Buschendorf, F. Hartung, J. M. Krois, AkademieVerlag, Berlin, s. 181205.

/// Krois J.M. 2009. Einletung, [w:] Edgar Wind, Heilige Furcht und andere Schriften zum Verbältnis von Kunst und Philosophie, red. J. M. Krois, R. Ohrt, Philo Fine Arts, Hamburg, s. 9-40.

/// Latella C. 2009. Wind and Riegl. The Meaning of a Problematical Grammar, „Journal of Art Historiography”, 1, s. 1-47.

/// Lloyd Jones H. 1983. A Biographical Memoir, [w:] Edgar Wind, The Eloquence of Symbols. Studies in Humanist Art, red. Jaynie Anderson, Oxford University Press, Oxford.

/// Lloyd Jones H. 1993. A Biographical Memoir, [w:] Edgar Wind, The Eloquence of Symbols. Studies in Humanist Art, red. Jaynie Anderson, Clarendon Press, Oxford.

/// MacLeish A. 1940. The Irresponsibles. A Declaration, Duell, Sloan \& Pearce, New York.

/// Ohrt R. 2009. ... ein Umweg. Nachwort, [w:] Edgar Wind, Heilige Furcht und andere Schriften zum Verbältnis von Kunst und Philosopbie, red. J. M. Krois, R. Ohrt, Philo Fine Arts, Hamburg, s. 395-425. 
/// O'Malley J.W. 2001. The Religious and Theological Culture of Michelangelo's Rome, 1508-1512, [w:] Edgar Wind, The Religious Symbolism of Michelangelo. The Sistine Ceiling, red. Elizabeth Sears, Oxford University Press, Oxford.

/// Ott H. 1993. Martin Heidegger. A Political Life, tłum. A. Blunden, Basic Books, London, s. 133-260.

/// Paulson R. 1987. Review of „Hume and the Heroic Portrait”, „EighteenthCentury Studies", 20, 4, s. 472-475.

/// Peirce Ch.S. 1934. Collected Papers of Charles Sanders Peirce, red. Charles Hartshorne, Paul Weiss, t. V, Harvard University Press, Cambridge, Massachusetts.

/// Peirce Ch.S. 1955. How to Make Our Ideas Clear, [w:] tegoż, Philosophical Writings of Peirce, red. Justus Buchler, Dover, New York.

/// Safranski R. 1998. Martin Heidegger. Between Good and Evil, tłum. E. Osers, Harvard University Press, Cambridge, Massachusetts and London, s. 225263.

/// Schneider P. 2009. Begriffliches Denken - verkörpertes Sehen. Edgar Wind (1900-71), [w:] Ideengeschichte der Bildwissenschaft. Siebzebn Porträts, red. Jörg Probst, Jost Philipp Klenner, Suhrkamp, Sinzheim, s. 53-73.

/// Schneider P. 2011. Die Aufgabe is gestellt. Nachwort, [w:] Edgar Wind, Ästhetischer und kunstwissenschaftlicher Gegenstand. Ein Beitrag zur Methodologie der Kunstgeschichte, red. P. Schneider, Philo Fine Arts, Hamburg, s. 357-378.

/// Steinberg L. 2001. Leonardo's Incessant Last Supper, Zone Books, New York.

/// Thomas B. [wkrótce]. In Defence of Marginal Anarchy. Edgar Wind and the Congress for Cultural Freedom, [w:] Art History and the Cold War, red. Grant Pooke, Ben Thomas, Ashgate, Farnham.

/// Tyler P. 1967. The Divine Comedy of Pavel Tchelitchew, Weidenfeld and Nicolson, London

/// Wind Archive, Special Collections, Bodleian Library, Oxford.

/// Wind E. 1924. Aesthetischer und kunstwissenschaftlicher Gegenstand. Ein Beitrag zur Methodologie der Kunstgeschichte. Auszug der Inaugural-Dissertation, Universität Hamburg. 
/// Wind E. 1925a, Contemporary German Philosophy, „Journal of Philosophy", 22, 18, s. 477-493.

/// Wind E. 1925b. Zur Systematik der künsterischen Probleme, „Zeitschriftf ür Ästhetik und allgemeine Kunstwissenschaft”, XVIII, s. 438-486.

/// Wind E. 1925c. Theory of Art versus Aesthetics, „The Philosophical Review" 34, s. 350-359.

/// Wind E. 1931. Warburgs Begriff der Kulturwissenschaft und seine Bedeutungfür die Ästhetik, „Zeitschrift für Ästhetik und allgemeine Kunstwissenschaft”, 25, s. 163-179.

/// Wind E. 1932. Humanitäts idee und heroisiertes Porträt in der englischen Kultur des 18. Jahrbunderts, [w:] tegoż, England und die Antike, Vorträge der Bibliothek Warburg 1930-1931, Teubner, Leipzig and Berlin, s. 156-229.

/// Wind E. 1934. Das Experiment und die Metaphysik. Zur Aufösung der kosmologischen Antinomien, J. C. B. Mohr, Tübingen.

/// Wind E. 1946a. Jean-Paul Sartre. A French Heidegger, „The Smith College Associated News", March, s. 1-4.

/// Wind E. 1946b. Blood Iron and Intuition, „Polemic”, 5, SeptemberOctober, s. 54-57.

/// Wind E. 1947. Sante Pagnini and Michelangelo. A Study of the Succession of Savonarola, „Mélanges Henri Focillon, Gazette des Beaux-Arts”, 6, XXVI, s. 211-246.

/// Wind E. 1948a. Bellini's Feast of the Gods. A Study in Venetian Humanism, Harvard University Press, Cambridge, Massachusetts.

/// Wind E. 1948b. The Critical Nature of the Work of Art, [w:] Music and Criticism. A Symposium, red. R. French, Harvard University Press, Cambridge, Mass., s. 55-72.

/// Wind E. 1952a. Mathematics and Sensibility, „The Listener”, 1 May, s. 705-706.

/// Wind E. 1952b. The Last Supper, „The Listener”, 8 May, s. 748.

/// Wind E. 1952c. Leonardo as a Physiognomist, „The Listener”, 15 May, s. 788 . 
/// Wind E. 1954. [Hamburg Speech], [w:] Wissenschaft Und Freiheit. Internationale Tagung Hamburg, 23.-26. Juli 1953, Grunewald Verlag, Berlin, s. 280281.

/// Wind E. 1958. Microcosm and Memory. Letter to the Editor, „The Times Literary Supplement”, 30 May 1958.

/// Wind E. 1967. Pagan Mysteries in the Renaissance, Penguin, Harmondsworth.

/// Wind E. 1969. Giorgione's Tempesta with Comments on Giorgione's Poetic Allegories, Oxford University Press, Oxford.

/// Wind E. 1983. The Eloquence of Symbols. Studies in Humanist Art, red. Jaynie Anderson, Oxford University Press, Oxford.

/// Wind E. 1985. Art and Anarchy, przedm. John Bayley, Duckworth, London.

/// Wind E. 1986. Hume and the Heroic Portrait, [w:] tegoż, Hume and the Heroic Portrait. Studies in Eighteenth-Century Imagery, red. Jaynie Anderson, Clarendon Press, Oxford, s. 1-52.

/// Wind E. 2001a. Das Experiment und die Metaphysik. Zur Auflösung der kosmologischen Antinomien, red. B. Buschendorf, Suhrkamp, Frankfurt am Main.

/// Wind E. 2001b. Experiment and Metaphysics. Towards a Resolution of the Cosmological Antinomies, tłum. C. Edwards, przedm. M. Rampley, Legenda, Oxford.

/// Wind E. 2001c. The Religious Symbolism of Michelangelo. The Sistine Ceiling, red. Elizabeth Sears, Oxford University Press, Oxford.

/// Wind E. 2009. Heilige Furcht und andere Schriften zum Verbältnis von Kunst und Pbilosophie, red. J. M. Krois, R. Ohrt, Philo Fine Arts, Hamburg.

/// Wind E. 2011. Ästhetischer und kunstwissenschaftlicher Gegenstand. Ein Beitrag zur Methodologie der Kunstgeschichte, red. P. Schneider, Philo Fine Arts, Hamburg.

/// Zorach R. 2007. Love, Truth, Orthodoxy, Reticence: or, What Edgar Wind Didn't See in Botticelli's Primavera, „Critical Inuiry”, 34, 1, s. 190-224. 